\title{
Epidemiology of maternal mortality in Befelatanana maternity during 2016-2017
}

\author{
Tanjona A. Ratsiatosika ${ }^{1 *}$, Romuald Randriamahavonjy ${ }^{2}$, Tahiana Rakotonirainy ${ }^{1}$, Marie \\ Valérie Rajaonarivony $^{1}$, A. Lantonirina Rainibarijaona ${ }^{3}$, Thierry Randrianambinina ${ }^{4}$, Ando- \\ Miora Rakotonirina ${ }^{1}$, Jean de la Croix Rasolonjatovo ${ }^{5}$, \\ Rakotovao Andianampanalinarivo Hery ${ }^{2}$
}

\begin{abstract}
${ }^{1}$ Department of Public Health, Faculty of Medicine, Antananarivo, Madagascar
${ }^{2}$ Department of Obstetrics and Gynecology, Befelatanana Hospital Center, Faculty of Medicine Antananarivo, Madagascar

${ }^{3}$ Department of Obstetrics and Gynecology, Soavinandriana Hospital Center, Faculty of Medicine Antananarivo, Madagascar

${ }^{4}$ Department of Intensive care unit, Befelatanana Hospital Center, Faculty of Medicine Antananarivo, Madagascar

${ }^{5}$ Department of Obstetrics and Gynecology, Toamasina, Faculty of Medicine Toamasina, Madagascar
\end{abstract}

Received: 31 May 2019

Accepted: 02 July 2019

*Correspondence:

Dr. Tanjona A. Ratsiatosika,

E-mail: ratsiatosika.tanjona@gmail.com

Copyright: ( $)$ the author(s), publisher and licensee Medip Academy. This is an open-access article distributed under the terms of the Creative Commons Attribution Non-Commercial License, which permits unrestricted non-commercial use, distribution, and reproduction in any medium, provided the original work is properly cited.

\section{ABSTRACT}

Background: Maternal mortality remains a permanent obsession for the pregnant woman and her entourage, and is still one of the topical issues faced by a developing country, such as Madagascar. Our study aims to determine the epidemiological and etiological profile.

Methods: We conducted a descriptive retrospective study over a 2-year period from January $1^{\text {st }}$, 2016 to December $31^{\text {st }}, 2017$ at the Befelatanana Gynecology-Obstetrics Hospital on maternal deaths.

Results: We had 76 maternal deaths out of 5430 births, or $1.39 \%$. The average age was $31.18 \pm 8.38$ years with extremes of 14 and 49 years. The average parity was $2.67 \pm 1.85$. The majority of pregnancies were poorly followed with a mean ANC of $2.18 \pm 1.85$. The referred patients predominated at $68.42 \%$. Women living in the urban area had a $57.89 \%$ majority. Among the etiology, hypertensive complications predominated at $42.11 \%$ followed by hemorrhagic $(38.16 \%)$ and infectious $(19.14 \%)$ complications. The patients who underwent surgery predominated at $78.94 \%$ and $59.21 \%$ were transfused.

Conclusions: Maternal mortality remains a major concern at the Befelatanana Obstetrics Gynecology Hospital. During our study, hypertensive complications were found to be the most common causes requiring adequate management. For this, an awareness of pregnant women for the standardization of ANC, as well as regular training of health actor are necessary.

Keywords: Epidemiology, Maternal death, Mortality related to pregnancy, Preclampsia

\section{INTRODUCTION}

Maternal and perinatal mortality continues to be a major public health problem. According to the WHO, maternal mortality is the death of a woman during pregnancy or for 42 days after the end of pregnancy, irrespective of the duration and site of the pregnancy, from any cause related to or aggravated by the pregnancy or its management but 
not from accidental or incidental causes. ${ }^{1}$ Information for maternal mortality serves many different purposes globally and locally, ranging from, for example, improving awareness in local communities, to global monitoring of progress towards Millennium Development Goal-5. Worldwide, more than half a million women die in peripartum period in developing countries. Maternal deaths are not uniformly distributed throughout the world, and obstetric risk is highest by far in sub-Saharan Africa. In Africa, it ranges from 228 per 100,000 live births (Abidjan) to 559 per 100,000 in Conakry. ${ }^{2,3}$ This rate does not exceed 31 per 100,000 births in developed countries. ${ }^{4}$ Proper management of the main etiology of maternal death will reduce the risk of maternal deaths. However, this will mean health workers and communities must develop the necessary capacity to respond appropriately to the management of emergency obstetric complications.

The objectives of this study were to determine the epidemiological and etiological profile of maternal mortality. Consequently, the obtained data would enable us to find potential preventive solutions by presenting these data to the healthcare officials.

\section{METHODS}

This is a retrospective and descriptive study of cases of maternal death seen at the gynecology and obstetrics hospital of Befelatanana. Cases of maternal death throughout the pregnancy or within 42 days of delivery were retained. The period studied was two years from January 1, 2016 to December 31, 2017.

We excluded accidental maternal death. The collection of the data was done on the Excel Stat 2007 Software. The statistical analysis was done by the $\mathrm{R}$ version 3.5 .2 software.

\section{The parameters studied were}

- Sociodemographic characteristic of patients: maternal age, gestity, parity, marital status, profession, ethnic group

- Obstetrical parameters: number antenatal care, gestational age, antecedent of scarred uterus

- Characteristic of maternal death: time to death of maternal death after admission, period of maternal death, site of maternal death

- Etiology of maternal death divided into three groups (death by maternal hypertension, pregnancy-related hemorrhage, infectious)

- Treatment done during hospitalization.

\section{RESULTS}

There were 76 maternal deaths out of 5430 births during the study period, or 1399 per 100,000 live births. The mean age of our patients was 31.18 years with extremes of 14 and 49 years (Table 1). The mean parity was
$2.67 \pm 1.85$, with multiparous prevalence at $51.31 \%$, followed by $15 \%$ primiparous (Table 1 ). The majority of the deceased women were married $(50 \%)$ of whom $35.53 \%$ were unemployed and $39.47 \%$ were in the primary sector (Table 1 ).

Table 1: Sociodemographic characteristics of patients.

\begin{tabular}{|ll|}
\hline Variables & \\
\hline Maternal age (years) & \\
\hline mean & $31.18 \pm 8.38$ \\
\hline Min-max & $14-49$ \\
\hline Gestity & $3.12 \pm 1.86$ \\
\hline mean & $1-8$ \\
\hline Min-max & \\
\hline Parity & $2.67 \pm 1.87$ \\
\hline mean & $0-8$ \\
\hline Min-max & \\
\hline Marital status n $(\%)$ & $12(15.79)$ \\
\hline Single & $23(30.26)$ \\
\hline Concubine & $38(50.00)$ \\
\hline Married & $3(3.95)$ \\
\hline Divorced & $0(0)$ \\
\hline Widow & \\
\hline Profession $\mathbf{n}(\%)$ & $27(35.53)$ \\
\hline Housewife & $30(39.47)$ \\
\hline Primary sector & $17(22.37)$ \\
\hline Secondary sector & $2(2.63)$ \\
\hline Tertiary sector & \\
\hline Residence n $(\%)$ & $44(57.89)$ \\
\hline Urban & $32(42.11)$ \\
\hline Rural & $65(86.67)$ \\
\hline Ethnic group n $(\%)$ & $1(1.33)$ \\
\hline Merina & \\
\hline Betsileo & \\
\hline Sakalava & \\
\hline & \\
\hline & \\
\hline
\end{tabular}

Table 2: Obstetrical parameters.

\begin{tabular}{|ll|}
\hline Variables & $\mathrm{n}=76$ \\
\hline Scarred uterus n $(\%)$ & $8(10.67)$ \\
\hline Antenatal care $(\mathbf{A N C )}$ & \\
\hline Mean \pm SD & $2.18 \pm 1.87$ \\
\hline Min-max & $0-7$ \\
\hline Gestationnal age & \\
\hline Mean \pm SD & $29.72 \pm 10.83$ \\
\hline Min-max & $9-40$ \\
\hline
\end{tabular}

The majority of pregnancies were poorly followed with a mean ANC of $2.18 \pm 1.85$. Mean gestational age was $29.72 \pm 10.83$ weeks of amenorrhea and ranged from 9 to 40 weeks of amenorrhea (Table 2).

The referred patients predominated at $68.42 \%$, of whom $28.95 \%$ were shocked at admission. Sixteen patients attempted a delivery outside the hospital (21.05\%) (Table 3). 
Table 3: Clinical parameters.

\begin{tabular}{|ll|}
\hline Variables & $\mathrm{n}=76$ \\
\hline Referred $\mathrm{n}(\%)$ & $52(68.42)$ \\
\hline Vaginal birth attempt $\mathrm{n}(\%)$ & $16(21.05)$ \\
\hline Shock at admission & $22(28.95)$ \\
\hline
\end{tabular}

Table 4: Maternal death characteristics.

\begin{tabular}{|c|c|}
\hline Variables & $\mathrm{n}=76$ \\
\hline \multicolumn{2}{|c|}{ Duration after admission } \\
\hline Mean \pm SD (hours) & $31.75 \pm 31.20$ \\
\hline Min-max & $1-120$ \\
\hline \multicolumn{2}{|c|}{ Period of maternal death $n(\%)$} \\
\hline $1^{\text {st }}$ trimester & $14(18.42)$ \\
\hline Antepartum & $4(5.26)$ \\
\hline Intrapartum & $3(3.95)$ \\
\hline Postpartum & $55(72.37)$ \\
\hline \multicolumn{2}{|c|}{ Site of maternal death $n(\%)$} \\
\hline Emergency unit & $4(5.26)$ \\
\hline Delivery room & $2(2.63)$ \\
\hline Operating theatre & $10(13.16)$ \\
\hline Intensive care Unit & $60(78.95)$ \\
\hline
\end{tabular}

With regard to death characteristics, the mean time to death compared with admission was $31.75 \pm 31.20$ hours, with extremes of 1 to 120 hours, the majority of our patients die in postpartum period $(72.37 \%)$ in intensive care unit $(78.95 \%)$ (Table 4$)$.

Table 5: Etiology of maternal death.

\begin{tabular}{|ll|}
\hline Etiologies & $\mathrm{n}=76$ \\
\hline $\begin{array}{l}\text { Hypertensive disorder and complication } \\
\mathrm{n}(\%)\end{array}$ & $32(42.11)$ \\
\hline Hemorrhage during pregnancy n (\%) & $29(38.16)$ \\
\hline Infectious n (\%) & $15(19.74)$ \\
\hline
\end{tabular}

During this period, maternal mortality secondary to hypertensive disorders and its complications predominated. Thirty-two cases of death were related to this pathology, i.e. $42.11 \%$. Haemorrhage was the second leading cause of death $(38.16 \%)$. Infectious causes were found in $19.74 \%$ of cases (Table 5).

Eclampsia was the leading cause of maternal death secondary to high blood pressure during pregnancy. More than half died following the complication of eclampsia. HELLP syndrom was responsible for $21.88 \%$ of deaths (Figure 1).

Regarding maternal deaths secondary to haemorrhage, uterine atony constituted half of the causes $(51.72 \%)$. uterine rupture was the second cause. Hemorrhagic complications of abortion accounted for $10.34 \%$ of cases (Figure 2).
In infectious complications, compications for illegal abortion accounted for $53.33 \%$ of cases. Puerperal infections and complications of spontaneous abortion each accounted for $20 \%$ of infectious causes (Figure 3 ).

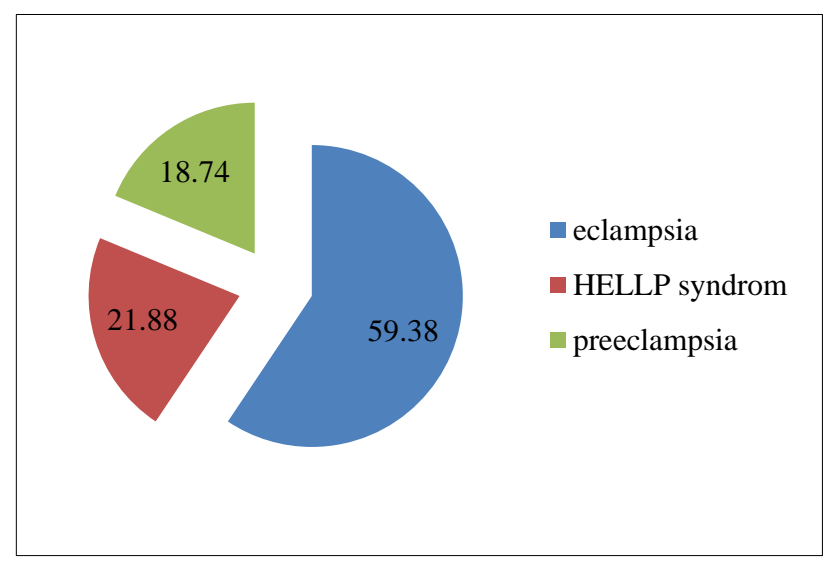

Figure 1: Cause of maternal death due to hypertensive disorder.

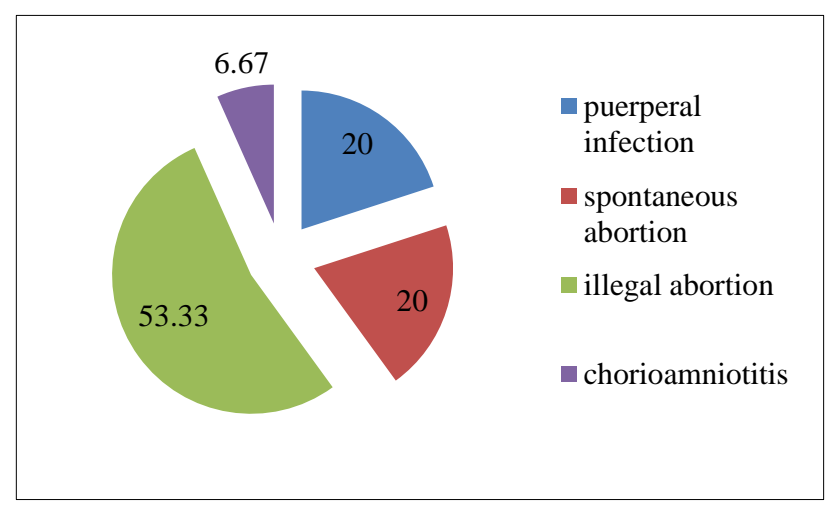

Figure 3: Cause of maternal death due to infection.

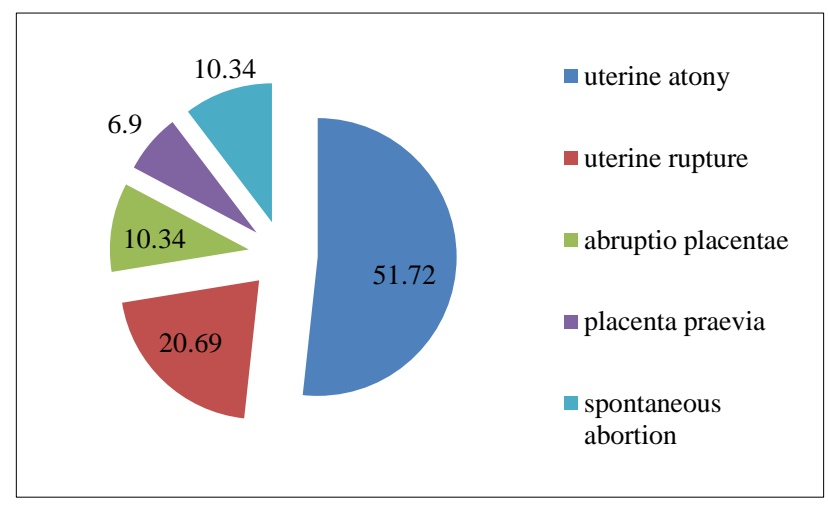

Figure 2: Cause of maternal death due to hemorrhage.

The majority of our patients had surgery including $47.37 \%$ caesarean section and $31.58 \%$ of laparotomy and emergency peripartum hysterectomy, $59.21 \%$ of the deceased patients were transfused (Table 6). 
Table 6: Therapeutic intervention during hospitalization.

\begin{tabular}{|ll|}
\hline Paramètres & $\mathrm{n}=76$ \\
\hline Intrauterine aspiration & $7(9.21)$ \\
\hline No surgical intervention & $4(5.26)$ \\
\hline Vaginal delivery & $5(6.58)$ \\
\hline Caesarean section & $36(47.37)$ \\
\hline Laparotomy and/or hysterectomy & $24(31.58)$ \\
\hline Blood transfusion $\mathrm{n}(\%)$ & $45(59.21)$ \\
\hline
\end{tabular}

\section{DISCUSSION}

The maternal mortality during pregnancy or within 42 days of birth is a medical, social, economic and political issue, as well as a human rights issue. ${ }^{5}$

In our study, we had 76 maternal deaths out of 5430 births, which is a prevalence of 1399 per 100,000 live births over a 2-year period. This frequency is very high compared to that generally recorded in African countries. ${ }^{6-8}$ A study conducted by Andriamady CL et al at the same hospital in 2000 found a mortality rate of 1250 per 100,000 live births, which is almost similar to our results. ${ }^{9}$ Ousmane $\mathrm{T}$ et al, in a study conducted at the King Baudouin Health Center (Mali) in 2005 had shown a mortality rate of 615 per 100,000 live births, comparable to that of M'baye 1at the health center Youssou M'bargane in Rufisque which reported a rate of 592 per 100,000 live births over a period of 7 months. ${ }^{10}$

However, it is far superior to those reported in developed countries where the maternal mortality rate is between 9 and 43 per 100,000 live births. ${ }^{11}$ The mortality rate in France was 9.1 per 100,000 live births, compared with 13.8 in North Carolina, 6.1 in Finland and 6.2 in Massachusetts. ${ }^{12} \mathrm{We}$ found that the maternal mortality rate is low in developed countries compared to developing countries, especially in Madagascar. Indeed, a reference delay following an unsatisfied means of transport, which led to the seriousness of the condition when the patients arrived in our center, could explain this situation.

The average age of our patients was $31.18 \pm 8.38$ years with extremes of 14 and 49 years, results superimposable to that reported by Moma (30 years) in a study conducted in Kaolack and Saint Louis. ${ }^{13}$ However, the study by Ousmani and his co-workers conducted in Senegal found younger women (28.4 years). ${ }^{10}$ Similarly for the study conducted by Andriamady CL et al, who had found an average age of 29 years with extremes of 15 and 48 years. ${ }^{9}$ Maternal age is a major risk factor for maternal mortality, with patients under the age of 20 and those aged 35 being the most affected. ${ }^{14,15}$

The average parity was $2.67 \pm 1.87$ with extremes of 0 and 8 , of which the multiparas were in the majority at $51.31 \%$ followed by the primiparous at $19.73 \%$. According to the
Andriamady et al study, the average parity was 4, with extremes ranging from 0 to $14 .^{9}$ According to Ousmane et al, the analysis showed that the number of deaths increased with parity. ${ }^{10}$ Thus, multiparous women accounted for $48.3 \%$ of deaths (149 cases) compared with $20 \%$ pauciparous (62 cases), $15.9 \%$ primiparous (49 cases), and $15.5 \%$ nulliparous (48 cases), almost similar to our results. This excess mortality of multiparas reported in our study was similar to data from African 6, 8 and Western literature. ${ }^{15-17}$ Multiparity is known as a risk factor of uterine atony and preeclampsiawhich are the main etiology of maternal death in our study.

An important component in the fight against maternal mortality is prenatal surveillance, the main objective of which is to detect and manage all pathologies in order to ensure safe motherhood. Well-attended antenatal care significantly reduces the risk of death during pregnancysepsis..$^{9,18,19}$

The results of our study showed that the majority of pregnancies were poorly followed with a mean ANC of $2.18 \pm 1.85$. These results were similar to data from Iloki et al 20, which found in its series in Congo that more than half of women were poorly or not followed during pregnancy. Similarly for Ousmane et al, one in four women had more than 3 prenatal consultations.

WHO recommends at least eight ANCs during pregnancy. ${ }^{21}$ This lack of ANC is unique to developing countries, where adverse socio-economic conditions have an influence on the monitoring of pregnancy. ${ }^{22}$

In our study, we found that $68.42 \%$ were evacuated, and Ousmane and his collaborators found that more than $50 \%$ of the women were evacuated. At the CHUs of Niamey and Ouagadougou the results were identical. ${ }^{23,24}$ This large proportion of evacuees among the cases of death could be explained by the fact that one is a center of reference and that the patients are admitted under bad conditions.

The study of maternal mortality has a particular connotation in the gynecology-obstetric services, because after a methodical analysis, it allows to establish the bases of a rational and effective prevention. The study of etiology in maternal mortality during the gravidpuerperium is difficult and complex.

The results of our study found, in order of decreasing frequency, hypertensive complications (42.11\%) dominated by eclampsia, which was $59.38 \%$, followed by haemorrhagic $(38.16 \%)$ and infectious complications (19.14\%). A study conducted by Rakotomahenina, in the same center, maternity Befelatanana Antananarivo (Madagascar) in the year 2005-2006 found that eclampsia is the leading cause of maternal mortality at $32 \%$, similar to our results but with a decreased rate. ${ }^{25}$ On the other hand, the study of Andriamady and his collaborators in the same center, in 1988-1997 over a period of 10 years 
had shown a predominance of infectious causes. ${ }^{9}$ The work of Ousmane et al, in a health center of King Boudouin (Dakar-Senegal) had found that hemorrhagic causes were majority, followed by hypertensive causes and indirect causes, this triad is found in the African literature. , $^{60-24,26}$

In developed countries, a study conducted in France from 1996-2002 over a period of six years found that hypertensive complications were in second position (12 to $14 \%$ of deaths, of which eclampsia was only $6 \%$. Hemorrhagic causes accounted for the majority of cases. ${ }^{27}$ Similarly, in the Netherlands, fewer maternal deaths are reported by complication of hypertension. ${ }^{28}$

Through our study, we have found that eclampsia is still ranked first among the causes of maternal deaths in our service compared to developed countries and other African countries. Eclampsia is just one of the complications of preeclampia. Preeclampsia is a pathology associating a gravidic arterial hypertension and a proteinuria $\geq 0,3 \mathrm{~g} / 24 \mathrm{H}$ occurring after $20 \mathrm{WA}$, these are signs that one could detect easily during a CPN and that an adequate care during its discovery could avoid the occurrence of eclampsia and other complications. However, we have a deficiency problem in antenatal care that only patients consult at the stage of complications. In our study, the majority of pregnancies were poorly followed with an average ANCof $2.18 \pm 1.85$, this could be explained by the lack of awareness to come in prenatal consultation. In addition, this situation is probably due to a lack of health education, and some beliefs against the use of drugs and health actor. ${ }^{26}$

For the study in Bangladesh, the authors report that the very high rate of eclampsia is due to the fact that only $2.3 \%$ of pregnant women have been medically supervised, and the rest do not have access to obstetric care. $^{29}$

\section{CONCLUSION}

Maternal mortality remains a major problem in Madagascar as well as in developing countries. Hypertensive causes dominated by eclampsia are the leading cause of maternal deaths at the Obstetrics and Gynecology Teaching Hospital Befelatanana (Antananarivo). Awareness of all pregnant women to come to prenatal consultation is necessary to detect early pathologies of pregnancy including preeclampsia to be able to lead adequate care. Political leaders are urged to ensure that mother-child health is privileged, while making a supply of the necessary drugs within the hospital, and to ensure that its medicines are accessible by everyone, in short, an improvement of the health system is desirable. Progress will ultimately be dependent on strong health systems ensuring high coverage of midwifery services supported by timely and competent hospital care.
Funding: No funding sources

Conflict of interest: None declared

Ethical approval: The study was approved by the Institutional Ethics Committee

\section{REFERENCES}

1. Mbaye M, Gueye SM, Gueye M. Les soins obstétricaux et néonataux d'urgence au centre niveau II de Rufisque: impact du redéploiement du personnel de la maternité du CHU Le Dantec. Journal de la SAGO. 2006;7(1):5-10.

2. Bohoussou KM, Djanhan Y, Bokossa E, Kone N, Welffens E, Toure K, et al. La mortalité maternelle à Abidjan (Côte d'Ivoire) de 1988 à 1993. Médecine de l'Afrique Noire. 1995;42:567-71.

3. Diallo MS, Sidibe M, Keita N. La mortalité maternelle. À propos de 212 observations en sept ans, à la Maternité Saint-Ignace Deen de Conakry (Guinée). Rev Fr Gynecol Obstet. 1989;84:419-22.

4. UNFPA. UNFPA-rapport annuel 2006. Available at: https://www.unfpa.org/sites/default/files/pubpdf/ar2006_fre.pdf, Accessed on 11 $1^{\text {th }}$ June 2019.

5. Coppieters Y, Bivort P, Madani K, Metboul M. Analyse des facteurs de la mortalité maternelle dans le sud algérien. Santé Publique. 2011;23(5):413-26.

6. Leke RJ. Outcome of pregnancy and delivery at the Central maternity of the Central Hospital of Yaoundé. Ann. Univ. Sc Santé Yaoundé. 1987;4:300-22.

7. Merger R, Levy J, Melchor J. Précis d'Obstétrique. MASSON, 5ème édition, Paris. 1985:205.

8. Diallo D. Etude de la mortalité maternelle au cours de la gravido puerperalité à Dakar. Thèse Méd. Dakar. 1977:32.

9. Andriamady CL, Rakotoarimanana M., Ranjalahy RJ. Mortalité maternelle à la maternité de Befelatanana CHU d'Antananarivo (1988-1997). J Gynecol Obstet Biol Reprod. 2000;29:501-8.

10. Ousmane T, Mamadou LC, Mouhamadou MN, Alioune G, Alassane D, Jean CM. Mortalité maternelle au centre de sante roi baudouin de (dakar - senegal) : à propos de 308 cas. Mali Medical. 2014;3.

11. Natalia AG, Siri V, Lisaforse N. Maternal mortality in Ste Petresburg, Russian Federation. Bulletin World Health Org. 2006;84:283-9.

12. Deneux C, Berg C, Bouvier CMH, Gissler M, Harper $\mathrm{M}$, Nannini A, et al. Underreporting of pregnancy related mortality in the United States and Europe. Obstet Gynecol. 2005;106:684-92.

13. Aboubakary AS. La mortalité maternelle au CHU de Kara: incidence, causes et facteurs de risque. J de la SAGO. 2006;7(1):21-5.

14. Ana CL. Adolescent maternal mortality in mozambique. J Adolescent Health. 2001;28:303-6.

15. Gurino NA, Vangen S, Forsen L, Sundby J. Maternal mortality in St Petersburg,Russian Federation. Bull World Haelth Organ. 2006;8(44):283-9. 
16. Institut national de la santé et de la recherche médicale(ISERM). Rapport du Comité National d'Experts sur la mortalité maternelle. France. 2006:75.

17. Degroof D, Issoufou Y. Importance d'une méthode démographique indirecte pour l'estimation de la mortalité maternelle: l'expérience du NIGER. Médecine d'Afrique Noire. 1997;44(4):192-4.

18. Diallo FB, Diallo AB, Diallo Y. Mortalité maternelle et facteurs de risques liés au mode de vie. Médecine d'Afrique Noire. 1998;45(12):723-7.

19. Bah AO, Diallo MH, Coude AM. HTA et Grossesse: mortalité maternelle et périnatale. Médecine d'Afrique Noire. 2001;48(1):461-4.

20. Iloki LH, G'balo S M, Kpekpede F. Mortalité maternelle à Brazzaville 1993-1994. J Gynecol Obstet Biol Reprod. 1997;26:163-8.

21. OMS. Rapport sur la santé dans le monde. OMS. 2005. Donnons sa chance à chaque mère et à chaque enfant. 2005. Disponible sur. Available at: http://www.who.int/whr/2005/chapter3/fr/index2.htm 1, Accessed $3^{\text {rd }}$ March 2009.

22. WHO/UNICEF. Low birth weight country, regional and global estimates. Données mises à jour fournies par les bureaux extérieurs de UNICEF. 2005. Available at: http://www.unicef.org/publications /index_24840.html, Accessed on 3rd March 2009.

23. Bouvier MH. Mortalité maternelle dans les pays en développement. Données statistiques et amélioration des Soins Obstétricaux. Med Tropicale. 2003;63:358-65.
24. Akar ME. Maternal death and their causes in Ankara, Turkey, 1982-2001. J Health Popul Nurs. 2004;22(4):420-8.

25. Rakotomahenina H, Rajaonarison TJ, Randriamahavonjy R, Andrianampanalinarivo $\mathrm{H}$. Pourquoi l'éclampsie engendre une forte mortalité ? Une étude dans la Maternité de Befelatanana. RARMU. 2009;1(3):25-7.

26. Dumont A, Bernis DEL, Boulin D. Morbidité maternelle et qualification du personnel de santé: comparaison de deux population différentes au Sénégal. J Gynecol Obstet Biol Reprod. 2002;31:709.

27. Bouvier $\mathrm{CMH}$, Philibert M. Épidémiologie de la mortalité maternelle en France, fréquence et caractéristiques. Réanimation. 2007;16:358-65.

28. Schutte JM. Rise in maternal mortality in the Netherlands. BJOG. 2010;117:399-406.

29. Begum MR, Begum A, Quadir E, Akhter S, Shamsuddin L. Eclampsia: Still a Problem in Bangladesh. Med Gen Med. 2004;6(4):52.

Cite this article as: Ratsiatosika TA,

Randriamahavonjy R, Rakotonirainy T, Rajaonarivony MV, Rainibarijaona AL, Randrianambinina T, et al. Epidemiology of maternal mortality in Befelatanana maternity during 2016-2017. Int J Reprod Contracept Obstet Gynecol 2019;8:3234-9. 